DOI: $10.31866 / 2410-1915.21 .2020 .207868$

UDC 008:504.61](477)

\title{
ECOLOGICAL CULTURE IN THE CONTEXT \\ OF THE CONCEPT OF SUSTAINABLE DEVELOPMENT: THE UKRAINIAN REALITIES AND PROSPECTS
}

\author{
Maryna Bratitsel
}

Assistant, ORCID: 0000-0001-9206-3479, frog2014137@gmail.com, Kyiv National University of Culture and Arts, 36, Ye. Konovaltsia St., Kyiv, 01133, Ukraine

\section{For citations:}

Bratitsel, M. (2020). Ecological Culture in the Context of the Concept of Sustainable Development: the Ukrainian Realities and Prospects. Culture and Arts in the Modern World, 21, 42-53. https://doi. org/10.31866/2410-1915.21.2020.207868.

The purpose of the article is to identify the features of the development of ecological culture in the modern Ukrainian society according to the concept of the sustainable development. The research methodology is based on the use of the axiological method, which provided the harmonization of knowledge, moral and spiritual development of a person, and contributed to the identification of a personal perception of nature as selfworth and a man. The system approach helped to describe an object as a systematic whole in terms of its structure, elements, purpose, and functions. The historical and logical method contributed to the study of dynamic transformations of relationships in the system "man-nature-society"; according to the sociocultural ecological culture is a type of world-view and a way of mastering social and cultural experience in accordance with the principle of co-evolution. The scientific novelty lies in the identification of trends in the ecological innovation culture as a part of the sustainable development concept and current environmental initiatives of domestic entrepreneurs in the process of modernization of the Ukrainian society. Conclusions. The study has shown that environmental sustainability has become an integral part of business practices in all areas of the human activity. It includes: the improvement of living standards by protecting human health, preserving the environment, efficient use of resources and ensuring long-term economic competitiveness. Thus, the definition of sustainability focuses on four areas: education, process, community participation, and future conditions.

Though, the concept of sustainable development has not become widespread in the Ukrainian practice, there are several hundred public environmental organizations, associations and movements at the state and regional levels. Ecological guidelines of upbringing, culture and education based on the ecological consciousness and morality by rethinking the environmental safety in the material and moral spheres become expedient in the context of the prospects of the development. It has been identified that the main task of the Ukrainian society is to increase the demand for the ecological innovations and

(C) Maryna Bratitsel, 2020

The article was received by the editorial office: 24.04 .2020 
the current trend - the program of supporting sustainable development as the best way for a manufacturer to demonstrate its care and attention to consumers. It has been defined that the main trend in the development of the ecological culture in the context of the European integration processes should be the formation of a model of ecoculture based on the moral and spiritual dominant of the world perception in the public consciousness, a change in the sociocultural mentality and responsible attitude to the environmental issues.

Keywords: ecological culture; sustainable development; Ukrainian society; environment.

\section{Introduction}

Modern global environmental challenges contribute to the comprehension of the dependence of the human civilization development on the level of the ecological culture - a universal system that combines environmental knowledge, standards, norms and values that are implemented in the ecological behaviour of a man.

The social and environmental problems strengthened attention to the search for the alternative ways of the social development in the last third of the $20^{\text {th }}$ century. One of them is the concept of sustainable development, which is the ideological basis for social change. This is an attempt to go beyond traditional ideological systems and comprehension, primarily through a system of categories and values, in which the person occupies a central place. Sustainable development is characterized by an innovative quality in the historical process, which is a natural result of the centuries-old human's desire for harmony.

In the context of global and glocal transformations against the backdrop of a noticeable environmental deterioration, the issue of ecoculture and its manifestations in real processes as an important component of the modern society's sustainable development is now becoming particularly relevant and requires cultural understanding and systematization of the accumulated knowledge.

Thus, the whole complex of economic, social and political, sociocultural transformations of the second decade of the $21^{\text {st }}$ century has characterized both the Ukrainian and the world society, requires a rethinking of the ecological culture formation in the context of the transformational processes in the sociocultural space. And globalization processes have foregrounded research on the ecocultural issues with the support of multicultural practices, taking into account regional and national peculiarities in their integrity.

The extreme actualization of the theme of ecological culture in the context of the future existence of mankind has caused considerable attention of scientists. At the beginning of the $21^{\text {st }}$ century, there were many publications in the foreign and domestic scientific space. The publication of O. Mateiuk (2007), devoted to the study of the ecological culture of an individual as a prerequisite for the implementation of the strategy for the country's sustainable development, analyses the content of the concept "sustainable development" and considers it as a strategy for implementing the interconnected development of nature, society, culture and human consciousness. It defines that safe ecological development is primarily an issue of the individual and collective consciousness (Mateiuk, 2007, p. 265). V. Lohvynenko (2011) made the theoretical substan- 
tiation of the essence of ecoculture and its components. He emphasizes that ecological culture involves not only knowledge about the scientific foundations of the relationship between society and nature, but also socially valuable motives in relation to it, the necessary skills and attitudes to the natural environment"(p. 37). I. Kachur (2011) in his research "Issues of the formation of ecological culture in the educational environment" justified the importance of environmental education in the process of ecoculture formation. The works of L. Kurniak (2015), L. Morozova, I. Kyryliuk and K. Mykhalevych (2015) analyse the current state and particularities of the formation of ecoculture of students and the ways of dealing with them. O. Zhykharieva (2013) studies the cultural approach to the ecological discourse, which is aimed at forming of an innovative, ecological world-view and "provides the evolution of the future environmentally conscious society and the internal ecological culture of an individual".

However, this issue requires an in-depth study of the development trends of ecological culture as a component of the concept of the sustainable development of the Ukrainian society.

\section{Purpose of the article}

The purpose of the article is to identify the features of the development of ecological culture in the modern Ukrainian society according to the concept of the sustainable development.

The research methodology is based on the use of the axiological method, which provided the harmonization of knowledge, moral and spiritual development of a person, and contributed to the identification of a personal perception of nature as self-worth and a man. The system approach helped to describe an object as a systematic whole in terms of its structure, elements, purpose, and functions. The historical and logical method contributed to the study of dynamic transformations of relationships in the system "man-nature-society"; according to the socio-cultural ecological culture is a type of world-view and a way of mastering social and cultural experience in accordance with the principle of co-evolution.

\section{Main research material}

The rapid development of the world economy and the growth of production resulted in the excessive use of natural resources, which negatively affects the environment, leads to the structural problems and reduces the ability of the society to respond effectively to modern environmental challenges. An example is the growth in the size of the hole in the ozone layer and global warming caused by the greenhouse effect. Therefore, understanding of this threat on the scale of human civilization will contribute to the development of technologies aimed at reducing the negative impact of the industry on the environment.

At the present stage, environmental sustainability has become an integral part of the business practices in all areas of human activity. The term "sustainable" in the sense of "a method of obtaining or using a resource so that 
the resource is not depleted or permanently damaged" has existed since around 1924. (Sundkvist et al., 2005, p. 226). Population growth and the corresponding increase in the negative impact on the environment in the last third of the $20^{\mathrm{th}}$ century contributed to the creation of the context from which the concepts of "sustainable development" and "sustainability" emerged, the definition of which varies depending on the field of application.

For the first time, the term "sustainable development" was used in 1972 at the First global conference on the environment in Stockholm, and in 1987, the concept of the sustainable development acquired the status of a scientific phenomenon, the classic definition of which is "a model of moving forward, which meets the needs of present generation without compromising the ability of future generations to meet their needs" (Butlin, 1989, p. 285). Currently, there are more than 50 different interpretations of the concept's definition, moreover, their number is growing depending on the dynamics of comprehension of the future development, which is uncertain and multiple. Most of them are formulated by scholars under the influence of the definition adopted at the World Summit on Sustainable Development in 2002, according to which sustainable development is the improvement of living standards by protecting human health, preserving the environment, efficient use of resources and ensuring long-term economic competitiveness.

In particular, R. Gibson (2006), developing the three-pronged concept of sustainable development proposed by E. Barbier, states that the relationship between the environmental, social, and economic aspects of "sustainability" - economic efficiency, social balance, and environmental protection - is indisputable, and developed as a response to quantitative environmental and economic data on non-viability in the long run of the economic growth trends of that time. The destruction of the environment at any scale will directly affect the social and economic sector of the human activity. Since the purpose of the sustainable development is to achieve a high standard of living, prosperous economy, and environmental preservation, sustainable practices should cover these three areas of activity (Gibson, 2006, p. 177).

Environmental sustainability involves preserving the integrity of natural systems and maintaining the viability of the biosphere; the social component is aimed at maintaining the stability of social and cultural systems, which includes fair distribution of benefits, preserving social stability, preventing conflicts, preserving cultural heritage, etc.; the economic component involves the idea of achieving optimal and maximally rational use of limited natural resources (the model of a balanced economy).

The definition of sustainability focuses on four areas - education, process, community participation, and future conditions, which are common to different definitions of sustainability and together offer a direction for the development of the effective practice.

"Sustainability" is now a global concept of potential solutions to many international, regional, and local problems of modern society, such as overpopulation, diseases, political conflicts, destruction of infrastructure, environmental pollution, and unlimited urban expansion with limited resources. 
Undoubtedly, the concept of sustainable development implies not only a systematic unity of economic, social and environmental types and aspects of the activities of the members of the modern society, but also an integral relationship between development and security. First of all, it provides opportunities for the existence of many different biological forms and species of life on the planet under condition of favourable existence of future and modern generations of people. Accordingly, the development of ideas related to the implementation of sustainable development involves the search and creation of optimal conditions for ensuring a harmonious existence within the triad "man-nature-society".

It should be emphasized that, defining the urgent issues of modern society's ecoculture, researchers focus on human activities that transform nature regardless of its scale and lead to the fatal destruction of the "nature-society" system, in which a man becomes a subject of destruction. Thus, ecological culture as a social phenomenon provides for the human activity's direction on the preserving of the necessary natural conditions for life, respectively, the level of ecoculture is determined by quantitative and qualitative indicators of the implementation of this direction.

At the present stage, the significant potential of the concept of sustainable development is generally recognized, but in Ukraine it has not become widespread in practice, and accordingly, the transformation processes in the economic, environmental and social dimensions are at an early stage. Despite the importance of integration of the foundations of sustainable development onto the regional level, the implementation of this concept has proved challenging in practice. In fact, integration of the environmental, economic and social aspects of sustainable development on the regional level implies implementation of additional and coordinated actions in different areas, which contributes to the economic growth and the achievement of social objectives without endangerment the rare resources of the planet (Jovovic et al., 2017, p. 257).

It should be noted that the development of the regions of Ukraine as a complex development of the Ukrainian society (social, economic, environmental, health, technological, cultural and recreational) in a specific area should be based on the optimal components of the expansion (aspects of social, natural and economic development), aimed at maintaining a certain standard of living and improving the quality of these components. Accordingly, regional development includes not only traditional policies on a specific territory, but also a social and economic process organised in a specific political and cultural context. Thus, the sustainability of the region is the organization of a process for improving the people's quality of life in conditions of limited use of natural resources. It includes solutions for improving the material well-being of people of a particular region that do not result in worsening of the environment or the well-being of other people. The sustainability concept implies:

- understanding of the relationship between the economy, society and the environment;

- life within certain limits of the earth's ability to sustain it;

- supporting of the fair distribution of the resources and opportunities for this and future generations. 
The national model of the Ukraine's sustainable development provides:

- the formation of civil society institutions, the rule of law and a socially oriented market economy;

- the consolidation of the Ukrainian society around the national idea based on the principles of democracy, freedom, humanism, the revival of national culture, respect for the universal values and natural resources.

It should be emphasized that the ecological consciousness of the modern Ukrainian society is characterized by a sharp perception of the environmental problems, understanding of interaction between man and nature, a high level of concern for the state of the environment and the need to obtain environmental knowledge. However, the interaction of the emotional component of the ecological knowledge with its activity component is contradictory in its character.

However, concern about the environmental situation in the country does not result in the increased activity as to its improvement - the passivity of a significant part of the Ukrainian society in the environmental area is due to the dominance of opinions about the institutional nature of environmental problems (the participation of the individual citizens in the process of improving of the country's environment is perceived as meaningless). As a result, the environmental situation deteriorates. So, in the Global Innovation Index 2019 (Global Innovation Index 2019) in the terms of environmental sustainability, Ukraine ranked $120^{\text {th }}$ among 129 countries in the world (the global innovation index 2019 contains information about the innovation activities of 129 countries. 80 indicators are used for the assessment and provide a complete picture of innovative development, including an overview of the political situation, the state of education, the level of infrastructure and business development, etc.). Analysing the current state of ecoculture in Ukraine, it should be noted that in comparison with the countries of Western Europe the level of the ecological culture of the domestic society is not high enough, due to following factors:

- the lack of environmental information (primarily due to the improper knowledge of the legal framework in the field of ecology and, at the same time, a low level of trust to the media);

- insufficiently active personal position regarding the protection of their own rights to a high quality of the environment (due to the lack of a clearly formed civil position in the society), etc.

The specifics of changes and indicators of the state of ecoculture in the modern Ukrainian society, in the consciousness of which the dominant focus is still on the consumption of the material goods, and the unlimited development of the production, and (that is, a meaningful anthropogenic and technogenic load on the environment) give reason to assume that the ecological consciousness and ecological culture of the Ukrainians is in the process of formation and development.

In the context of the prospects of the ecocultural development, ecological guidelines of upbringing, culture and education based on ecological consciousness and morality become expedient, which will be implemented in the conditions of the existence of the alternative views on the future of civilization, based on the values of each individual in particular and society in general. 
Prospects for the successful implementation of the theoretical models of the ecological culture in practice, of the management activities at the regional level, requires the development and introduction of the innovative social technologies focused primarily on the dynamic modernization of human activities and environmental improvement.

In Ukraine, in order to protect natural resources, improve the environment, increase the level of ecological culture and education of the Ukrainians, form ecological mentality at the state and regional levels there are several hundred public environmental organizations, associations and movements, the best known of which are: All-Ukrainian Environmental Non-Governmental Organisation "MAMA-86" (founded in 1993 as a city environmental organization "Kyiv Mothers Initiative for Child Protection"), All-Ukrainian Environmental League (founded in 1997), all-Ukrainian non-governmental organisation Living Planet, the association “Ecology. Law. Man”, Kyiv Ecological centre, The National Ecological Centre of Ukraine, etc. Central departments and public organizations regularly hold national (Environment Day (third Saturday of April), since 1998) and local environmental activities ("Green spring”, "Clean country - clean Earth", "Fauna", "Clean air"), mass environmental events ("Source", "Rivers of my childhood", "Living water”), all-Ukrainian festivals ("Eco-2000”), environmental activities, information and educational tours ("Climate of the future without threat to life!"), international symposiums ("Transport and environment”), conferences (All-Ukrainian conference of the environmental community), etc.

In December 2019, the Professional Association of Ecologists of Ukraine at a regular meeting of the working group determined the working directions for the Committee on industrial ecology and innovation for 2020 (previously, the priority areas for 2020 were determined by the Committees on water resources protection and water management, the Committee on the environmental monitoring and the waste management Committee) in the following areas:

- ensures a balance between the environmental safety and economic growth through the introduction of modern technologies;

- promotes the environmental modernization of the industrial enterprises in order to reduce the impact on the environment;

- deregulates in the field of the environmental protection in order to attract investment in the ecological projects;

- uses the public funds for environmental protection.

It should be emphasized that at the present stage, the main task of the Ukrainian society is to increase the demand for the environmental innovations - the so-called green process innovation (Marekha \& Omelyanenko, 2016, p. 11). Despite the dominant role of the state in regulating the innovation system, the role of the modern society is extremely important in the process of creating a stable demand for the environmental products through the desire of communities for ecological activities and behaviour, since the ecological culture of a certain economic environment is primarily related to the culture of a society of a certain territorial system as a whole. Researchers point out that it is the culture of the society that creates a steady demand for eco-innovation (Marekha \& Omelyanenko, 2016, p. 11). 
The most promising developments of the ecological culture in Ukraine are rethinking of the need to activate measures for environmental safety not so much in the material, but primarily in the moral and spiritual sphere by creating effective links between the subject-theoretical experience and realistic trends of the present time; ecocultural security through increased influence on the society of state and private structures (mass media, socialization institutions, public and charitable organizations, etc.).

World public organizations make demands for business, according to which it becomes unprofitable to continue activities that pollute the environment. Therefore, companies are announcing reduction in energy consumption, the introduction of modern industrial technologies and waste disposal, the creation of full-cycle production and the production of "eco-friendly" goods, and so on. The program of supporting sustainable development and ecology is becoming a current trend in the global industry as the best way for a manufacturer to demonstrate its care and attention to consumers. This program also works in Ukraine. In particular, in August 2019, the publication "Business" issued the top 10 environmental initiatives of domestic entrepreneurs. They include:

- strategic management of by-products and waste;

- reconstruction of the existing capacities and construction of new hydropower facilities;

- eco-friendly production of high-tech equipment;

- the European level of eco-friendly product; needs;

- energy cooperative producing renewable energy for their own energy

- systematic ecological modernization of the metallurgical complex;

- the modernization of obsolete equipment;

- voluntary commitments in the field of environmental protection;

- briquetting of grain and plant waste;

- one flew over the stork's nest... How the energy business saves the Ukrainian birds.

The effective integration of the main development aspects (social, natural and economic) in Ukraine requires a number of targeted and specific actions that complement each other and fit into the framework of sustainable development. The achievement of sustainability in the country involves finding solutions that balance the importance and impact of each of the three aspects in order to increase profits, improve the environment and people's lives.

\section{Conclusions}

Thus, in the last third of the $20^{\text {th }}$ century, population growth and environmental pollution created the conditions for the emergence of the concept of "sustainable development", "sustainability". Although today there is no single definition of this concept (it varies depending on the field of use, and there are more than fifty interpretations), most scholars believe that "sustainable development" includes: the improvement of living standards by protecting human 
health, preserving the environment, efficient use of resources and ensuring long-term economic competitiveness.

Therefore, environmental sustainability has become an integral part of business practices in all areas of the human activity and focuses on four areas: education, process, community participation, and future conditions. Thus, ecological culture as a social phenomenon provides for the human activity's direction on the preserving of the necessary natural conditions for life, respectively, the level of ecoculture is determined by quantitative and qualitative indicators of the implementation of this direction.

Sustainable development of the Ukrainian society involves meaningful integration of certain aspects of the Western ecological culture and their combination with traditional ecoculture, but the concept of sustainable development has not yet been very common in the Ukrainian practice. This is due to the fact that the population's concern about the environmental situation does not lead to the activation of its activities. This passivity of a certain part of the Ukrainian society is due to the dominance of opinions about the institutional nature of the ecological problems and orientation to the consumption of the material goods and the unlimited development of production.

Despite this, there are several hundred public environmental organizations, associations and movements at the state and regional levels. Ecological guidelines of upbringing, culture and education based on ecological consciousness and morality by rethinking the environmental safety not so much in the material, but primarily in the moral and spiritual spheres become expedient in the context of the prospects of the ecocultural development.

The main trend in the development of the ecological culture in the context of the European integration processes, in our opinion, should be the formation of a model of ecoculture based on the moral and spiritual dominant of the world perception in the public consciousness, a change in the socio-cultural mentality and personal responsible attitude to the environmental issues.

Thus, today, the main task of the Ukrainian society is to increase the demand for the ecological innovations - the so-called green process innovation. The program to support sustainable development as the best way for a manufacturer to demonstrate its care and attention to consumers is becoming a current trend in Ukraine.

\section{References}

Butlin, J. (1989). Our common future. By World commission on environment and development. Journal of International Development, 1(2), 284-287. https://doi. org/10.1002/jid.3380010208 [in English].

Gibson, R. B. (2006). Sustainability assessment: Basic components of a practical approach. Impact Assessment and Project Appraisal, 24(3), 170-182 [in English].

Jovovic, R., Draskovic, M., Delibasic, M., \& Jovovic, M. (2017). The concept of sustainable regional development - institutional aspects, policies and prospects. Journal of International Studies, 10(1), 255-266. https://doi.org/10.14254/2071-8330.2017/101/18 [in English]. 
Kachur, I.V. (2011). Problemy formuvannia ekolohichnoi kultury v osvitnomu seredovyshchi [Issues of the formation of ecological culture in the educational environment]. Nauka. Relihiia. Suspilstvo, 2, 209-213 [in Ukrainian].

Kurniak, L. M. (2015). Ekolohichna kultura: poniattia ta formuvannia [Ecological culture: concepts and formation]. Zbirnyk naukovykh prats Khmelnytskoho instytutu sotsialnykh tekhnolohii Universytetu "Ukraina", 10, 48-51 [in Ukrainian].

Lohvynenko, V. M. (2011). Teoretychni osnovy fenomenu ekolohichnoi kultury [Theoretical foundations of the phenomenon of ecological culture]. Visnyk of National Technical University of Ukraine "Kyiv Polytechnic Institute". Philosophy. Psychology. Pedagogics, 3, 34-38 [in Ukrainian].

Marekha, I., \& Omelyanenko,V. (2016). Cultural aspect of innovation strategies' ecologization. Economic Annals-XXI, 162, 9-12 [in English].

Mateiuk, O. (2007). Ekolohichna kultura osobystosti yak peredumova formuvannia staloho rozvytku krainy [Ecological culture of the individual as a prerequisite for the formation of sustainable development of the country]. The Scientific Issues of Ternopil Volodymyr Hnatiuk National Pedagogical University. Series: pedagogy, 9, 262-265 [in Ukrainian].

Morozova, L. P., Kyryliuk, I. A., \& Mykhalevych, K. V. (2015). Problemy ekolohichnoho vykhovannia molodi ta shliakhy yikh vyrishennia [Problems of ecological education of youth and ways of their solution]. Molodyi vchenyi, 12(3), 49-52 [in Ukrainian].

Rishennia v styli EKO: TOP-10 naiekolohichnishykh proektiv biznesu [ECO-style solutions: TOP-10 most environmentally friendly business projects]. (2019, August 1). Business. https://business.ua/special/102-spetsproekt-enerhiiaekolohiia-ekonomika/6037-rishennya-v-stili-eko [in Ukrainian].

Sundkvist, A., Milestad, R., \& Jansson, A. (2005). On the importance of tightening feedback loops for sustainable development of food systems. Food Policy, 30, 224239 [in English].

Ukraina opustylasia v reitynhu innovatsiinykh krain [Ukraine has dropped in the ranking of innovative countries]. (2019, July 25). Slovo $i$ dilo. https://www. slovoidilo.ua/2019/07/25/novyna/ekonomika/ukrayina-opustylasya-rejtynhuinnovaczijnyx-krayin [in Ukrainian].

Vyznacheno napriamy roboty na 2020 rik dlia Komitetu promyslovoi ekolohii ta innovatsii PAEU [The directions of work for 2020 for the Committee of Industrial Ecology and Innovations of PAEU are determined]. (2019, December 27). Ecobusiness Group. https://ecolog-ua.com/news/vyznacheno-napryamy-roboty-na-2020-rikdlya-komitetu-promyslovoyi-ekologiyi-ta-innovaciy-paeu [in Ukrainian].

Zhykharieva, O. O. (2013). Ekolohichnyi dyskurs: kulturolohichnyi pidkhid [Ecological discourse: a culturological approach]. Zhytomyr Ivan Franko State University Journal, 2(68), $74-77$ [in Ukrainian]. 


\title{
ЕКОЛОГІЧНА КУЛЬТУРА В КОНТЕКСТІ КОНЦЕПЦІЇ СТІЙКОГО РОЗВИТКУ: УКРАЇНСЬКІ РЕАЛІЇ ТА ПЕРСПЕКТИВИ
}

\author{
Братіцел Марина Леонідівна
}

\author{
Асистент, \\ ORCID: 0000-0001-9206-3479, frog2014137@gmail.com, \\ Київський національний університет культури і мистецтв, \\ Київ, Україна
}

Мета статті - виявити особливості розвитку екологічної культури в сучасному українському суспільстві відповідно до концепції стійкого розвитку.

Методологія дослідження полягає у використанні аксіологічного методу, який забезпечив гармонізацію пізнання та морально-духовного розвитку людини, сприяв визначенню особистісного сприйняття природи як самоцінності та людини. Системний підхід дозволив описати об’єкт як системне ціле з огляду його структури, елементів, мети та функцій. Історико-логічний метод сприяв дослідженню динамічних трансформацій взаємовідносин у системі «людина-природа-суспільство»; відповідно до соціокультурного екологічна культура - це тип світогляду та спосіб освоєння соціального і культурного досвіду згідно з принципом коеволюції. Наукова новизна полягає у визначенні тенденцій розвитку екологізації інноваційної культури як складової концепції стійкого розвитку та виявленні актуальних екологічних ініціатив вітчизняних підприємців у процесі модернізації українського суспільства. Висновки. У дослідженні виявлено, що невід’ємною частиною ділової практики всіх галузей людської діяльності стала екологічна стійкість, яка включає: підвищення рівня життя шляхом захисту здоров'я людей, збереження довкілля, ефективне використання ресурсів та забезпечення довготривалої економічної конкурентоспроможності. Тож, визначення стійкості зосереджено у чотирьох напрямах: освіті, процесі, участі співтовариств та майбутніх умовах.

Хоча концепція стійкого розвитку в Україні ще не отримала поширення на практиці, однак на державному і регіональному рівнях діє кількасот громадських екологічних організацій, об’єднань та рухів. Перспектив розвитку набувають екологічні орієнтири виховання, культури та освіти на основі екологічної свідомості і моралі шляхом переосмислення екологічної безпеки у моральній та духовній сферах. 3'ясовано, що головним завданням українського суспільства постає процес екологізації інноваційної культури, а нагальним трендом - програма підтримки стійкого розвитку як найвдалішого способу для виробників продемонструвати споживачам свою турботу та увагу суспільства. Доведено, що домінуючою тенденцією розвитку екологічної культури в умовах євроінтеграційних процесів має стати формування моделі екокультури на основі морально-духовної домінанти світосприйняття в суспільній свідомості, зміна соціокультурної ментальності та свідомого ставлення до проблем довкілля.

Ключові слова: екологічна культура; стійкий розвиток; українське суспільство; довкілля. 


\title{
ЭКОЛОГИЧЕСКАЯ КУЛЬТУРА В КОНТЕКСТЕ КОНЦЕПЦИИ
} УСТОЙЧИВОГО РАЗВИТИЯ: УКРАИНСКИЕ РЕАЛИИ И ПЕРСПЕКТИВЫ

\author{
Братицел Марина Леонидовна
}

Ассистент, ORCID: 0000-0001-9206-3479,frog2014137@gmail.com, Киевский национальный университет культуры и искусств, Киев, Украина

Цель статьи - выявить особенности развития экологической культуры в современном украинском обществе в соответствии с концепцией устойчивого развития. Методология исследования заключается в использовании аксиологического метода, который обеспечил гармонизацию познания и нравственно-духовного развития человека, способствовал определению личностного восприятия природы как самоценности и человека. Системный подход позволил описать объект как системное целое с точки зрения его структуры, элементов, цели и функции. Историко-логический метод способствовал исследованию динамических трансформаций взаимоотношений в системе «человек-природа-общество»; согласно социокультурному экологическая культура - это тип мировоззрения и способ освоения социального и культурного опыта в соответствии с принципом коэволюции. Научная новизна заключается в определении тенденций развития экологизации инновационной культуры как составляющей концепции устойчивого развития и выявлении актуальных экологических инициатив отечественных предпринимателей в процессе модернизации украинского общества. Выводы. В исследовании выявлено, что неотъемлемой частью деловой практики всех областей человеческой деятельности стала экологическая устойчивость, которая включает: повышение уровня жизни путем защиты здоровья людей, охраны окружающей среды, эффективное использование ресурсов и обеспечение долговременной экономической конкурентоспособности. Поэтому определение устойчивости сосредоточено в четырех направлениях: образовании, процессе, участия сообществ и будущих условиях. Хотя концепция устойчивого развития в Украине еще не получила широкого распространения на практике, однако на государственном и региональном уровнях действует несколько общественных экологических организаций, объединений и движений. Перспективы развития приобретают экологические ориентиры воспитания, культуры и образования на основе экологического сознания и морали путем переосмысления экологической безопасности в моральной и духовной сферах. Установлено, что главной задачей украинского общества является процесс экологизации инновационной культуры, а актуальным трендом - программа поддержки устойчивого развития как самого удачного способа для производителей продемонстрировать потребителям свою заботу и внимание общества. Доказано, что доминирующей тенденцией развития экологической культуры в условиях интеграционных процессов должно стать формирование модели экокультуры на основе морально-духовной доминанты мировосприятия в общественном сознании, изменение социокультурной ментальности и сознательного отношения к проблемам окружающей среды.

Ключевые слова: экологическая культура; устойчивое развитие; украинское общество; окружающая среда. 